\title{
Alejo Carpentier: um escritor em busca da América
}

\section{Alejo Carpentier: a writer in pursuit of America}

\author{
Felipe de Paula Góis Vieira ${ }^{1}$
}

\section{Resumo}

Este artigo analisa a trajetória política, intelectual e literária do escritor cubano Alejo Carpentier (1904-1980). Considerando alguns dos seus dados biográficos, a ideia é compreender como, em suas obras iniciais, se articula um projeto narrativo de descrição do continente americano. Fortemente influenciado pelas vanguardas europeias do pósguerra, Carpentier deu início à busca de uma identidade americana através da literatura. Ao analisar as obras Visión de América, El reino de este mundo e Los pasos perdidos, a intenção do artigo é compreender os protocolos através dos quais o autor empreende a busca por aquilo que ele classificou como o "real maravilhoso americano". O argumento central da análise é pensar como essa lógica discursiva de Carpentier dialoga diretamente com padrões narrativos europeus sobre a América.

Palavras-chave: América; literatura hispano-americana; realismo mágico; Alejo Carpentier.

\begin{abstract}
:
This article analyzes the political, intellectual and literary trajectory of the Cuban writer Alejo Carpentier (1904-1980). Considering some of his biographical, the idea is to understand how, in his early work, a narrative project describes the American continent. Strongly influenced by Postwar European vanguards, Carpentier began the search for an American identity through literature. Analyzing the books Visión de América, El reino de este mundo and Los pasos perdidos, the intention of this article is to understand the protocols used by the author to begin a search for what he described as the "real maravilhoso americano". The main argument of this work is to analyze how Carpentier's discursive logic dialogues directly with an European standards of narrative about America.
\end{abstract}

Keywords: America; Hispanic American literature; magical realism; Alejo Carpentier.

Artigo recebido em: 30/08/2014

Artigo aprovado para publicação em: 04/10/2014

Difícil evitar rótulos quando pensamos em Alejo Carpentier. Romancista, cronista, pai mítico da geração do boom latino-americano, musicólogo, crítico literário, jornalista, comunista, exilado? Em seus 75 anos de vida Carpentier fez uso de todas

\footnotetext{
${ }^{1}$ Licenciado e mestre em História Cultural pela Universidade Estadual de Campinas (UNICAMP), junto ao Departamento de História do Instituto de Filosofia e Ciências Humanas. Atualmente, desenvolve Doutorado pela mesma instituição, com o título História e literatura: a construção do passado hispanoamericano nos romances de Alejo Carpentier e Gabriel García Márquez, com financiamento de bolsa da CAPES. E-mail: felipepgv@yahoo.com.br.
}

\section{GANPHLAC}

Revista Eletrônica da ANPHLAC, ISSN 1679-1061, No. 17, p. 107-138, jul./dez. 2014. http://revista.anphlac.org.br 
essas atribuições, encarnando um tipo comum de intelectual latino-americano ${ }^{2}$ de início da segunda metade do século XX.

Nascido em Havana, em 26 de dezembro de 1904, fruto do casamento entre um arquiteto francês e uma professora de línguas de origem russa, Carpentier transformouse, como nos lembra Carlos Augusto de Melo (2010, p. 93), em um homem de múltiplos espaços, por circunstâncias diversas que, muito longe de representar um espírito aventureiro, o direcionaram curiosamente à visualização de vários lugares singulares, em especial, da América Latina. Viveu a infância em Cuba e distribuiu o restante dos anos entre França, Espanha, Haiti, México, Nova York e Venezuela.

Apesar do constante deslocamento, como afirma Otto Maria Carpeaux (1976, p. 6), foi em Paris que Carpentier passou grande parte de sua vida. Na capital francesa, o escritor cubano estudou arquitetura, música e história da música. Lá passou nada menos que onze anos, de 1928 a 1939, embora não voluntariamente. ${ }^{3}$ Também em Paris consolidou-se como jornalista e se associou, por mediação do poeta francês Robert Desnos, ao grupo surrealista. Enquanto permaneceu na capital francesa, colaborou com a causa dos revolucionários cubanos em sua luta contra Gerardo Machado, publicando artigos sobre as atrocidades do regime em revistas espanholas de esquerda, como Octubre, dirigida pelo literato Rafael Alberti.

No final dos anos 20 e início dos anos 30, Paris era a cidade que havia sido intermitentemente, desde o século XIX, a capital artística e cultural da América hispânica. Segundo González Echevarría (1985, p. 23), era nos cafés de Paris que os

\footnotetext{
${ }^{2}$ Ao falar em "tipo comum" de intelectual latino-americano, refiro-me à posição de apoio à Revolução Cubana, a uma postura política enquadrada dentro da esquerda política do continente, à experiência compartilhada do exílio e à inserção dentro do debate intelectual sobre o sentido e o significado do continente latino-americano no mundo ocidental. Certamente, os diversos literatos do período reagiram de formas distintas e pessoais às contingências de seu tempo histórico. Destaco, apenas, uma gama comum de características do chamado intelectual latino-americano da segunda metade do século XX. Para mais informações, consultar: GILMAN, Claudia. Entre la pluma y el fusil: debates y dilemas del escritor revolucionario en América Latina. Buenos Aires: Siglo XXI, 2003.

${ }^{3}$ Em 1927, Alejo Carpentier aproximou-se do grupo Minorista - associação intelectual que englobava cientistas sociais, literatos e músicos contra o imperialismo e as ditaduras políticas vividas pelo país, em especial, a ditadura de Gerardo Machado. Em 6 de maio desse ano, sua adesão ao Manifesto minorista resultou em prisão. Foram apenas 40 dias de cárcere, mas, em todo caso, ao sair da prisão Carpentier estava fichado, e sua permanência na ilha, comprometida. Na primavera de 1928 encontrou uma maneira de escapar de Cuba. Como conta González Echevarría, um congresso internacional de intelectuais se reuniu em Havana, com assistência do poeta surrealista Robert Desnos. Desnos aproximou-se de Carpentier e permitiu ao escritor o uso de seu passaporte para subir a bordo do barco que os levaria em direção à França. Essa fuga espetacular abriu para Carpentier um caminho comum a tantos outros escritores latino-americanos: o exílio (GONZÁLEZ ECHEVARRÍA, 1985. p. 22).
}

\section{GANPHLAC}

Revista Eletrônica da ANPHLAC, ISSN 1679-1061, No. 17, p. 107-138, jul./dez. 2014. http://revista.anphlac.org.br 
poetas cubanos conheciam os poetas chilenos, ou nas galerias da mesma cidade que compositores argentinos descobriam pintores mexicanos. O trânsito intelectual de personalidades latino-americanas era muito comum na cidade, e exemplo disso foram as amizades travadas e consolidadas por Carpentier no Velho Mundo. Foi em Paris que ele se fez amigo do guatemalteco Miguel Ángel Asturias, do venezuelano Arturo Uslar Pietri, do poeta chileno Pablo Neruda; também chegou a conhecer melhor os poetas e pintores cubanos como Nicolás Guillén e Wifredo Lam. De Paris, Carpentier viajou com frequência a Madri, onde conheceu Frederico García Lorca, Rafael Alberti, Miguel Hernández e muitos outros hispano-americanos que, sobretudo, na época da República, deram à capital espanhola uma efervescência artística e intelectual indispensáveis à formação intelectual de Carpentier.

Esses contatos com artistas e intelectuais de outros países latino-americanos proporcionaram ao escritor cubano uma consciência continental. Segundo González Echevarría (1985, p. 24), foi na capital francesa que Carpentier se deu conta de que seu esforço por incorporar a cultura negra na arte cubana encontrava eco no movimento indigenista de países como México e Peru. Esse estímulo impulsionou-o a assistir cursos de etnologia em Sorbonne e a passar largas horas nas salas de leitura da Biblioteca Nacional de Paris, onde devorou diversos livros sobre a América hispânica.

E, aqui, encontra-se uma ideia fundamental para o desenvolvimento do artigo. $\mathrm{O}$ exílio permitiu ao escritor cubano travar amizades e um profícuo diálogo com seus pares hispano-americanos, mas, sobretudo, formar-se nos círculos intelectuais europeus. É importante circunscrever essa geração de intelectuais hispano-americanos dentro de uma perspectiva que pensa a América a partir da Europa. Em outras palavras, a consciência do continente que eles constroem é dada de fora e através de uma lógica discursiva europeia.

Assim, Paris tornou-se o aparelho necessário para que fossem estabelecidas as diretrizes fundantes do projeto literário de Carpentier. Como nos conta Melo (2010, p. 94), foi de lá, sem dúvida alguma, que o escritor conseguiu pela primeira vez visualizar certa ideia de América e, a partir da perspectiva "do lado de fora", ter a possibilidade de “despertar" para os alicerces americanos no que diz respeito a um novo espaço de humanidade.

Obviamente, esse despertar só é possível àquele que se encontra em outro plano narrativo: em outras palavras, aquele que escreve sobre a América é também alguém

\section{GANPHLAC}

Revista Eletrônica da ANPHLAC, ISSN 1679-1061, Nº. 17, p. 107-138, jul./dez. 2014. http://revista.anphlac.org.br 
que se situa fora de sua realidade histórica. Assim, suas futuras descrições ou interpretações do continente americano nos indicam que a voz amplamente dominante é a de um europeu. Essa constatação permite perceber que, apesar de sua quase obsessão por se situar como intelectual ou escritor latino-americano, ao falar e descrever o continente, os parâmetros que adotou reproduzem, grande parte das vezes, uma forma de falar ou descrever a América que é europeia.

Portanto, os onze anos separados do mundo caribenho e do continente latinoamericano, com uma vida estruturada nos padrões da capital francesa, foram fundamentais para sua visão ou visões da América. Embora elabore, como veremos a seguir, um discurso que se pretende fundante sobre a identidade do continente, sua lógica discursiva não se desprende completamente de uma visão da América consagrada na Europa.

A tudo isso se soma um contexto bastante específico. É importante lembrar que Carpentier chega ao continente europeu num momento em que o mundo ocidental vivia a crise e as dúvidas geradas pelo pós-guerra. Como afirma a historiadora argentina Patricia Funes (2006, p. 13), por muitas razões, a Primeira Guerra Mundial limou todas as maiúsculas decimônicas da civilização ocidental: Razão, Civilização, Progresso, Ciência; e, pelos interstícios dessas incertezas, surgiram caminhos indisciplinados e heterodoxos para considerar o continente latino-americano.

A ideia operante e amplamente difundia entre a intelectualidade latinoamericana dentro e fora do continente, como assegura Funes, era aquela defendida por José Ingenieros: se os bárbaros europeus haviam se suicidado em uma guerra, o caráter de "civilização" poderia ser revisado, inclusive, invertido. ${ }^{4}$ Assim, voltava à pauta dos assuntos europeus e hispano-americanos a "juventude" da América Latina ante a "velha" Europa, desgastada e corroída pela guerra. O antieuropeísmo foi uma identificação geracional muito forte entre pensadores, ensaístas, intelectuais e artistas

\footnotetext{
${ }^{4}$ Obra capital deste período, escrita entre 1912 e 1917, publicada em 1918, A decadência do Ocidente, de Oswald Spengler, teve impacto fulminante sobre a intelectualidade dos anos 20. O livro propõe ciclos de civilizações, que - como seres orgânicos e biológicos - se sucedem em um continuum de nascimento, juventude e decadência. Assim, a história da humanidade havia sido percorrida por oito civilizações (egípcia, chinesa, babilônica, indiana, arábica ou mágica, antiga, mexicana e ocidental). E o Ocidente estaria em termos de desaparecimento, porque, em sua análise, a decadência era fatal e as culturas não voltariam a aflorar. Essa obra circulou exitosamente pela Europa e também pela América Latina. As críticas de Spengler ao eurocentrismo foram fundamentais para a fundação de muitas tradições intelectuais, culturais e políticas do século XX americano. Para melhor compreensão do tema, ver: FUNES, 2006.
}

\section{GANPHLAC}

Revista Eletrônica da ANPHLAC, ISSN 1679-1061, No. 17, p. 107-138, jul./dez. 2014. http://revista.anphlac.org.br 
latino-americanos. Em outras palavras, se o Ocidente era decadente, a América rejuvenescia e prometia. Certamente, essas ideias não passaram impunemente por Carpentier.

Assim, como afirma Melo (2010, p. 95), esse período como estrangeiro no continente europeu solidificou mais ainda no espírito carpentieriano a necessidade de voltar-se à América e percebê-la de diversos ângulos e, com isso, poder refletir sobre a sua grande importância em comparação às demais civilizações, principalmente em se tratando de seu caráter singular e original que, por extensão, fazia "conhecê-lo a si mesmo", como suposto indivíduo americano definido diante do mundo.

Em 1939, a situação era bastante tensa na Europa. A Guerra Civil Espanhola havia terminado com a derrota da República e a ascensão do governo do general Francisco Franco. Além disso, a iminência de um novo conflito mundial se fazia sentir em cada canto do velho continente. O retorno se fez necessário e, finalmente, em 1939, o escritor estava de volta à América, mais especificamente, de volta a Cuba.

Os seis anos que Carpentier passou em Cuba, entre 1939 e 1945, são de grande atividade artística e intelectual. Seus programas de rádio se constituíram em um grande êxito; e, para além disso, muitos laços de amizade foram estreitados com escritores e pintores renomados da ilha. A partir de então, o escritor passou a visitar o vasto território americano em busca de conhecer as suas peculiaridades.

Em 1945, depois de um tempo passado em Nova York, Carpentier se mudou para a Venezuela, com o intuito de trabalhar como sócio de uma estação de rádio com seu amigo Carlos Frias. Dois anos mais tarde, em um processo que incluiu a composição de Los pasos perdidos (1953), Carpentier fez duas viagens às nascentes do rio Orenoco, na Grande Savana Venezuelana. ${ }^{5}$

À época de suas viagens pelo continente, o escritor alcançara a casa dos 40 anos e, a partir de então, tentaria substituir a América hispânica que havia descoberto nos livros de Paris por outra experimentada em primeira mão, aqui no continente. É interessante pensar que essas inusitadas viagens interioranas tiveram como fim um passeio de conhecimento natural e antropológico. Nada mais europeu do que uma

\footnotetext{
${ }^{5}$ Essas viagens pelo interior do continente não eram novidade na vida do escritor. Antes da jornada empreendida pelo interior da Venezuela, ainda em 1943, o ator francês Louis Jouvet convenceu Carpentier a acompanhá-lo até o Haiti. O escritor cubano ficou maravilhado pelas ruínas da Revolução Haitiana, sendo esta uma experiência imprescindível para o processo de elaboração de El reino de este mundo.
}

\section{GANPHLAC}

Revista Eletrônica da ANPHLAC, ISSN 1679-1061, No. 17, p. 107-138, jul./dez. 2014. http://revista.anphlac.org.br 
viagem antropológica. E essa América buscada, mais do que descoberta, construída por Carpentier, acabou por formar os alicerces sobre os quais se ergueu a chamada nova narrativa hispano-americana, ${ }^{6}$ ou a literatura do real maravilhoso.

Suas viagens renderam uma série de relatos originalmente publicados no jornal El Nacional de Caracas e na revista Carteles sob a rubrica Visión de América. Também forneceram material suficiente para a elaboração de dois romances $-E l$ reino de este mundo (1949) e Los pasos perdidos (1953) -, que tornaram Carpentier um escritor famoso nos anos 50. Os relatos mais os romances serão, agora, tomados como fontes para se pensar qual imagem da América Carpentier constrói em suas obras iniciais.

\section{Visões da América: natureza indomável no coração do continente americano}

Em Visión de América, Carpentier concentrou sua narração na viagem que fez pelo povoado de Santa Elena de Uairén, descrevendo detalhadamente as novidades que encontrou quando realizou a aproximação com a natureza e seus respectivos habitantes, vistos como participantes do mundo perdido do Gênesis.

É interessante observar como essas descrições de Carpentier dialogam com os anos 20 da intelectualidade europeia. Como lembra Funes (2006, p. 35), o desgaste europeu do pós-guerra e a crítica corrosiva a Europa como centro irradiador de cultura geraram uma crise de sentidos que animou muitos intelectuais a recorrer ao exotismo e ao orientalismo. Desiludidos com a civilização ocidental, artistas e intelectuais descobriram com fascinação civilizações e culturas não europeias: Herman Hesse, a Índia [Sidharta, 1922], D. H. Lawrence, os astecas [A serpente emplumada], T. E. Lawrence, a Arábia. Em muitos casos, esses escritores foram os demiurgos a partir dos quais se produziu o encontro com uma América Latina vital e sensual, redescoberta do outro lado do oceano. Como veremos adiante, essa América encontra eco nos relatos de viagem elaborados por Carpentier em 1947. No entanto, a perspectiva que toma o escritor cubano ao descrever a América vem de um sentimento de pertencimento a uma

\footnotetext{
${ }^{6}$ Entre os anos de 1940 e 1955, constatou-se um vigoroso e complexo fenômeno de renovação ficcional dentro do continente hispano-americano. Segundo Irlemar Chiampi, essa narrativa reagia contra o realismo/naturalismo do século XIX e contra a chamada "novela da terra", um tipo de regionalismo que imperava nas primeiras décadas do século XX. Com o afã de catalogar suas tendências e encaixá-las sob uma denominação que significasse a crise do realismo que essa nova orientação narrativa patenteava, surgiram lugares-comuns no discurso crítico-literário sobre o romance hispano-americano: o realismo mágico, o real maravilhoso americano, a literatura fantástica, o barroco, o neobarroco ou, simplesmente, a nova narrativa hispano-americana (CHIAMPI, 1980. p. 19).
}

\section{GANPHLAC}

Revista Eletrônica da ANPHLAC, ISSN 1679-1061, No. 17, p. 107-138, jul./dez. 2014. http://revista.anphlac.org.br 
suposta identidade latino-americana. Isso tornará seu discurso diverso daquele desenvolvido pela literatura europeia do pós-I Guerra, muito embora essas viagens ao coração da América sejam, em parte, possíveis graças à literatura citada. Em 1949, no prólogo de El reino de este mundo, Carpentier negaria taxativamente todas as vanguardas europeias de início dos anos 20 como forma de consolidar a busca por uma estética própria da arte e da literatura na América Latina. O argumento desenvolvido é que essa busca por uma cultura específica do continente, que encontra sua base no "maravilhoso", já se esboça a partir dos relatos de viagem de 1947, embora, explicitamente, apareçam apenas a partir do prólogo mencionado.

Assim, em Visión de América, o que se destaca de imediato na narração feita pelo escritor cubano é um intenso e arrebatador maravilhamento diante da natureza e das culturas da "América profunda". ${ }^{7}$ No texto "A Grande Savana: mundo do Gênesis" surge a seguinte descrição das paisagens naturais do continente americano:

[...] nosso assombro está longe de serenar nosso pulso. Novos perante uma paisagem tão nova, tão inaugural como deve ter sido para o primeiro homem a paisagem do Gênesis, prossegue para nós a Revelação das Formas. [...] O automatismo imaginativo de minha cultura ocidental me faz evocar, no ato, o castelo de Macbeth ou o castelo de Klingsor. Mas não. Essas imagens limitadas são inadmissíveis no coração da América virgem. Estas torres de rocha acerada, levissimamente reluzente, são altas demais, ariscas demais sob este céu dramaticamente agitado que se desnuda sobre o vale de Karamata ao clarão de um raio que caiu muito longe, sobre as serras brasileiras. (CARPENTIER, 2006, p. 13)

A descrição, que mais se assemelha a um diário de bordo, constrói a sensação de estarmos diante de uma paisagem inaugural, ainda intocada pela presença humana. Essa natureza, possível apenas nos rincões da América, vista com deslumbramento e

\footnotetext{
${ }^{7}$ Em sua dissertação de mestrado, Flávia Preto de Godoy Oliveira analisou como, desde os primeiros contatos entre os europeus e a América, houve certa ênfase nos aspectos naturais em diferentes narrativas e imagens sobre o continente americano. Segundo a pesquisadora, a repetição desse discurso nas crônicas dos séculos XVI ao XVIII criou uma ideia bastante forte que associa o novo continente a uma região de predomínio do natural. Em outras palavras, a partir dos primeiros contatos e nos séculos seguintes, os cronistas europeus, ao escrever sobre o Novo Mundo - independente do assunto tratado -, também se referiam à sua natureza, a qual seria não apenas sua característica mais marcante, mas também determinante. Obviamente, como alerta a autora, a natureza americana também sofreu leituras sucessivas e sobrepostas, que vão de sua detratação ao engrandecimento. É possível perceber que as associações entre natureza e o status conferido à América e seus habitantes não cessaram nos três primeiros séculos de conquista e colonização, adentraram também o período contemporâneo. No século XIX hispanoamericano, o exemplo mais significativo é, talvez, o de Domingo Sarmiento, que em Facundo: civilização e barbárie apresenta-nos um quadro no qual a natureza é uma das responsáveis pela condição degenerativa do homem no pampa (OLIVEIRA, 2010. p. 33-34).
}

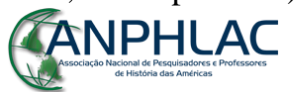

Revista Eletrônica da ANPHLAC, ISSN 1679-1061, No. 17, p. 107-138, jul./dez. 2014. http://revista.anphlac.org.br 
assombro, subverte qualquer comparação com padrões ocidentais. Por mais que o narrador tente a aproximação: Shakespeare ou Wagner produzem imagens limitadas demais para encontrar semelhança visual no coração da "América virgem". Além da exaltação da natureza americana em toda a sua grandiosidade, o trecho apresentado deixa entrever certa incompatibilidade entre o pensamento ocidental (nitidamente europeu) e a realidade que se apresenta no coração da selva americana.

Selva de natureza vencedora, capaz de barrar, inclusive, a presença da Conquista: "Aqui o símbolo da cruz teve de se deter mil vezes; aqui pereceram mercadores obscuros, com os ossos misturados aos de suas récuas" (CARPENTIER, 2006, p. 12).

No texto "O salto do anjo no Reino das Águas", essa natureza indomável volta a aparecer:

Subimos há menos de duas horas esse Caroni de águas escuras, quase negras em certos remansos, por vezes plúmbeas, ocres em um brechão, mas nunca amáveis; rio que desde o Descobrimento, descobrimento que mal roçou a sua boca, conserva uma raivosa independência - mais do que independência, virgindade feroz de amazona indomável, vencedora dos conquistadores ingleses, devoradora dos trezentos companheiros do português Álvaro Jorge, responsável por mil mortes sem história. (CARPENTIER, 2006, p. 18)

É importante perceber que a descrição da natureza americana em Carpentier encontra sempre um contraponto. Sua grandiosidade e ferocidade só existem na medida em que a comparação toma por ponto oposto a Europa. O aspecto quase épico que adquire a descrição natural da selva americana ganha destaque na medida em que conquistadores ingleses são vencidos ou portugueses devorados por sua vastidão. Certamente, a América que Carpentier constrói em seus relatos obedece a um propósito narrativo: é preciso encontrar uma essência americana capaz de prostrar os baluartes da presença europeia. Nem Shakespeare nem o Descobrimento têm importância diante da grandiosa natureza do continente.

Nesse sentido, até mesmo o descobridor se rende em estupefação:

Impossível imaginar algo mais impressionante que o salto de Tobarima, dado pelo Caroni em meio à selva mais cerrada e feroz, para manter-se em gargantas onde mal se pode acreditar que caiba tanta água. É que o Caroni é um rio estrondoso, rio que brama em seus canhões, que retumba em trovão ao pé de suas torrentes, tanto que

\section{GANPHLAC}

Revista Eletrônica da ANPHLAC, ISSN 1679-1061, No. 17, p. 107-138, jul./dez. 2014.

http://revista.anphlac.org.br 
Walter Raleigh, ao conhecer esse trovão de água, o qualificou como "horroríssono cataclismo líquido". (CARPENTIER, 2006, p. 19)

Pela descrição oferecida, não há outra reação possível senão espanto diante desse rio estrondoso, sendo quase possível imaginar um Walter Releigh pequenino, quase desprezível, diante da grandiosidade natural que se lhe oferece. Em "O último buscador do Eldorado", até mesmo o clima é digno de admiração: "reservou-se um terreno para o cemitério, cujas covas só receberam, até a data, quatro corpos vitimados por acidentes, já que o clima maravilhoso da Grande Savana não é dos que provocam doenças" (CARPENTIER, 2006, p. 39).

O entusiasmo e admiração frente à natureza americana possuem tradição narrativa na história do continente. É importante lembrar que a descrição que oferece Carpentier da Grande Savana assemelha-se muito àquela consagrada pelo naturalista prussiano Alexander von Humboldt ${ }^{8}$ no final do século XVIII e início do XIX. Aceito pelos meios acadêmicos como portador de um discurso científico verdadeiro e de alto mérito, Humboldt, segundo alguns estudiosos, também foi considerado pela elite hispano-americana como interlocutor sobre os assuntos do continente americano. Como nos lembra Mary Louise Pratt, o naturalista prussiano foi o interlocutor mais importante no processo de reimaginação e redefinição da América após os processos de independência, constituindo uma imagem do continente que foi apreciada pelos habitantes tanto do Novo quanto do Velho Mundo.

Suas visões da natureza, ainda segundo Pratt, estão profundamente alicerçadas nas construções setecentistas de Natureza e Homem,

o indivíduo observador de Humboldt é também uma cópia exata e autoconsciente dos primeiros europeus inventores da América, Colombo, Vespúcio, Raleigh e outros. Eles também descreveram a América como um mundo primitivo de natureza, um espaço devoluto e atemporal ocupado por plantas e criaturas (algumas delas humanas), mas não organizado em sociedades e economias; um mundo cuja única história era aquela prestes a se iniciar. Seus escritos também

\footnotetext{
${ }^{8}$ Como lembra Oliveira, Humboldt desembarcou na América pela primeira vez em 16 de julho de 1799 . Percorreu grande extensão do continente fazendo descrições detalhadas daquilo que julgava ser a cultura e a natureza americana. Tornou-se, em poucos anos após o seu retorno à Europa, uma referência em relação aos estudos sobre a natureza e as sociedades do Novo Mundo. Importância que pode ser notada a partir do epíteto que foi e continua lhe sendo atribuído em muitas biografias: o redescobridor científico do continente americano ou o segundo descobridor da América (OLIVEIRA, 2009. p. 127-128).
}

\section{GANPHLAC}

Revista Eletrônica da ANPHLAC, ISSN 1679-1061, No. 17, p. 107-138, jul./dez. 2014. http://revista.anphlac.org.br 
retrataram a América em meio a um discurso de acúmulo, abundância e inocência. (PRATT, 1999, p. 220-221)

Assim, como nos lembra Oliveira (2010, p. 185), a representação humboldtiana da natureza americana consagra uma visão na qual o continente apresenta-se como um espaço onde elementos físicos têm maior preponderância em relação aos povos e culturas nele presentes.

Luiz Estevam de Oliveira Fernandes (2009, p. 61-63), apoiado em Pratt, afirma que, em seu afã categorizador, Humboldt engrandeceu a natureza americana, praticamente apagando-lhe o elemento humano, para ressaltar em seu texto uma imensa "terra virgem". Ainda segundo Fernandes, o efeito de esvaziar o palco para fazer reinar a Natureza teve uma consequência bastante peculiar: uma imagem da América como um local com possibilidades e riquezas múltiplas e, por isso mesmo, aberto à exploração, preferencialmente, daquele que vem de fora. Além disso, Humboldt acabou sancionando a ideia criolla de uma América grandiosa e pujante.

Além dessa aproximação com Humboldt, Carpentier toma sempre como ponto de partida, para sua descrição da América, referenciais europeus: Shakespeare, Wagner, rios europeus etc. Essa intenção de fazer ver ou conhecer o mundo americano cria a impressão de que essa realidade é descrita para uma comunidade de leitores europeus, situados do "lado de fora" daquilo que é descrito.

Nesse sentido, o encantamento e o assombro diante da natureza americana em Carpentier são construídos através do diálogo com narrativas europeias sobre o continente. Mas é importante sublinhar que, embora não fuja de uma forma europeia de descrever a América, dentro de sua busca por uma identidade hispano-americana, a negação da Europa se torna elemento narrativo fundamental. Ou seja, se por um lado há o maravilhamento com as paisagens ainda virgens da América, há, por outro, uma detratação de tudo aquilo que se relaciona com a Europa.

Apesar de tudo, o Fundador de Cidades, o descobridor de diamantes, o iluminador de veios não enriquecia. E não enriquecia por ter descoberto algo situado além de toda a sede de ouro: a inutilidade do ouro para qualquer indivíduo que não deseje retornar a uma civilização que não apenas inventa a bomba atômica, mas que além disso é capaz de inventar justificativas metafísicas para explodi-la. (CARPENTIER, 2006, p. 40)

\section{GANPHLAC}

Revista Eletrônica da ANPHLAC, ISSN 1679-1061, Nº. 17, p. 107-138, jul./dez. 2014. http://revista.anphlac.org.br 
O Ocidente não é apenas engolido pela selva americana, é também descrito e enquadrado sob a ótica decadente do pós-guerra. Em "A Bíblia e a ogiva no âmbito do Roraima", o "frenético homem do ocidente" é também "fazedor de gerações cada vez mais curtas e débeis" (CARPENTIER, 2006, p. 31). Em “Ciudad Bolívar, metrópole do Orenoco", Carpentier rende-se diante da magnificência do Alto Orenoco, ironizando "certos rios europeus de derramada retórica poética e pouca água de verdade".

Para descrever sua viagem até as nascentes do rio Orenoco, como nos lembra Dernival Venâncio Ramos Júnior (2004, p. 21), Carpentier elege seus interlocutores. Lança mão de toda uma tradição de relatos de viagens, aproximando-se de uns e se afastando de outros. Além do citado Humboldt, aproxima-se dos viajantes e das crônicas do Descobrimento, que buscavam na América o Paraíso Terrestre e o Eldorado. Mas é importante destacar que, se por um lado, na narrativa de Carpentier, há uma América construída com assombros de admiração, muito próxima das crônicas do XVI, há, por outro, uma Europa descartada, débil, pequena diante da realidade americana.

Segundo González Echevarría (1985, p. 44), a fonte principal dessas afirmações de Carpentier é o livro A decadência do Ocidente, de Oswald Spengler, que, na tradução espanhola de Manuel García Morente, prefaciada por Ortega, teve um impacto enorme sobre todo o mundo de língua espanhola, especialmente na América hispânica. Para Carpentier e muitos outros artistas e intelectuais americanos, o Novo Mundo estava em um momento de plenitude, enquanto o Ocidente estava em decadência.

O que faz Carpentier em suas descrições da selva americana é repetir um lugarcomum do discurso intelectual latino-americano da década de 1920: o velho continente europeu enfrentando a pujança do novo continente americano. Como nos lembra Edmundo Paz Soldán (2008, p. 37), em 1941, seis anos antes dos textos analisados, Carpentier, influenciado pelas teses de Spengler, já havia escrito um texto catastrófico intitulado "El ocaso de Europa". Nesse texto, o continente americano era visto como repositório "de la antorcha de la civilización”, que

ha pasado del viejo corredor exhausto a las manos del atlético y juvenil campeón americano... Los ciclos europeos están colmados. Y esto lo demuestra, más que nada, el auténtico fracaso de las democracias europeas. (CARPENTIER apud PAZ SOLDÁN, 2008, p. 37)

\section{GANPHLAC}

Revista Eletrônica da ANPHLAC, ISSN 1679-1061, No. 17, p. 107-138, jul./dez. 2014.

http://revista.anphlac.org.br 
Humboldt, as crônicas da Conquista, Spengler e as correntes intelectuais de detratação da Europa pós-II Guerra ajudaram Carpentier a construir sua versão da América. Certamente, diante do colapso europeu, Carpentier não estava sozinho. Como salienta Páz Soldán, as ideias mundonovistas na literatura latino-americana de princípio do século haviam resultado em movimentos tão importantes como o regionalismo dos anos 20, e logo evoluíram, nos anos 40, com a aparição do que o crítico uruguaio Ángel Rama chamou em sua obra de "narradores de la transculturación": escritores como José María Arguedas, Miguel Ángel Asturias, Augusto Roa Bastos e o próprio Carpentier, que tinham por intenção dar conta narrativa da complexa mescla de culturas na América Latina. Emir Rodríguez Monegal também menciona "un crecimiento de la conciencia nacional [...] que estimula la obra de ensayistas que se vuelcan cada vez con más ahínco a una doble indagación del país y el ser latinoamericano" (apud GONZÁLEZ ECHEVARRÍA, 1974, p. 11-12).

Nesse sentido, cresce vertiginosamente a importância de se pensarem as descrições narrativas que apresenta Carpentier da natureza americana. Por que resgatar uma América de natureza densa, virgem, quase anterior à Conquista? Por que insistir no caráter vencedor desta natureza diante da colonização e dos baluartes da cultura ocidental? Como resposta a essas perguntas, apresenta-se um contexto amplamente favorável de contestação à Europa e suas noções do que é "civilizado" ou "civilização". Essas discussões, contempladas em seus textos, marcam a construção da identidade no continente, tendo como referência a negação da Europa e a afirmação de uma especificidade americana. Em outras palavras, ao tornar texto suas impressões sobre a “América profunda", Carpentier realiza um amplo processo de procura por uma essência americana, constatada pelo escritor numa suposta realidade empírica do continente.

Em “O salto do anjo no Reino das Águas”, uma passagem, em especial, chama a atenção:

Acontece que a América alimenta e conserva os mitos com o encanto de sua virgindade, com as proporções de sua paisagem, com sua perene "revelação de formas" - revelação que, vale lembrar, deixou atônita a Espanha da Conquista, a ponto de Pedro Mártir de Anglería, desapontado com um viajante que se vangloriava de ter achado carvalhais, olivedos e azinhais em sua expedição, dizer: "Para que precisamos dessas coisas banais na Europa?". Porque a Espanha, deslumbrada com as coisas que chegavam nas arcas dos navegantes,

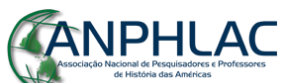

Revista Eletrônica da ANPHLAC, ISSN 1679-1061, Nº. 17, p. 107-138, jul./dez. 2014. http://revista.anphlac.org.br 
maravilhada com os relatos dos aventureiros afortunados, já acostumada a pronunciar novas palavras e nomes, a saber de Potosí e do Reino de Cuzco, do Inca e de Teocali, também se acostumava a aceitar que, na América, o fantástico se tornava realidade. (CARPENTIER, 2006, p. 23)

Como tenho afirmado, a literatura produzida por Carpentier engaja-se de maneira explícita na marcação da diferença frente à Europa. O que significa dizer que, acima de tudo, a América descrita, construída em seus relatos é diferente da realidade europeia. Resgatar essa América quase virgem, anterior ao Descobrimento, é, sobretudo, uma tentativa de conferir unidade ao continente através da contemplação de sua vasta natureza. Posto dessa forma, os relatos apresentam similar preocupação ideológica, concentrada no tratamento das ideias românticas de originalidade americana. O exótico, o extraordinário, o desconhecido, o escondido, natural da Grande Savana e do Alto Orenoco, revelam aspectos que, de alguma maneira, na ótica de Carpentier, expõem uma suposta história de unidade da humanidade hispano-americana.

Também é importante observar que, nesse trecho, Carpentier introduz um argumento crucial de sua literatura e, por assim dizer, da literatura que se desenvolveu no continente na década de 1960. Para o escritor, a América encontra sua especificidade na presença e vigência de mitos que na Europa há muito foram sepultados nas gavetas empoeiradas da retórica e da erudição. Esses mitos, mais do que ledos engodos, histórias da carochinha, fariam parte da realidade empírica do continente, em especial da "América virgem". A vigência de uma realidade maravilhosa, diversa da tão propagada racionalidade europeia, seria expandida no texto "Lo real maravilloso en América", publicado originalmente em 1948.

\section{El reino de este mundo: América como espaço do maravilhoso}

Esto se me hizo particularmente evidente durante mi permanencia en Haití, al hallarme en contacto cotidiano con algo que podríamos llamar lo real maravilloso. Pisaba yo una tierra donde millares de hombres ansiosos de libertad creyeron en los poderes licantrópicos de Mackandal, a punto de que esa fe colectiva produjera un milagro el día de su ejecución. [...] A cada paso hallaba lo real maravilloso. Pero pensaba, además, que esa presencia y vigencia de lo real maravilloso no era privilegio único de Haití, sino patrimonio de la América entera, donde todavía no se ha terminado de estabelecer, por ejemplo, un recuento de cosmogonías. (CARPENTIER, 1984, p. 8)

\section{GANPHLAC}

Revista Eletrônica da ANPHLAC, ISSN 1679-1061, No. 17, p. 107-138, jul./dez. 2014.

http://revista.anphlac.org.br 
América como espaço do maravilhoso: esta seria uma ideia fundamental para um texto que, anos mais tarde, seria classificado como o prólogo por excelência do romance hispano-americano. O texto em questão, "Lo real maravilloso en América", foi publicado originalmente no El Nacional da Venezuela, transformando-se, em 1949, no prólogo de El reino de este mundo - segundo romance de Alejo Carpentier.

Com esse romance, o autor começou a busca do que definia por "real maravilhoso". Esse conceito teve na época uma ampla difusão; como salienta Jorge Quiroga (1984, p. 21), apareceu, implícita ou explicitamente, como o fundamento posterior da narrativa hispano-americana. No prólogo do romance, famoso, por muito tempo mais conhecido e citado que a própria obra, Carpentier coloca tal ideia como problemática específica da cultura na América Latina.

Segundo Irlemar Chiampi (1980, p. 136), há certa concordância de que o romance hispano-americano da segunda metade do século XX é representativo de uma consciência da dimensão histórica do homem latino-americano. Essa consciência de que fala Chiampi pode ser facilmente observada no prólogo de Carpentier: seu texto é um posicionar-se diante do mundo, em especial, diante do mundo europeu. Ao tentar encontrar o sentido da imagem da América Latina, o escritor acaba criando um pastiche amplamente difundido pela literatura do período: a América "maravilhosa", "mágica", bastante diversa da realidade racionalista europeia.

Para tanto, o escritor começa rememorando uma viagem que havia feito ao Haiti em 1943, e utiliza essa visita para articular uma primeira oposição entre Europa e América, entre realidade e arte. A "maravillosa realidad" do Haiti, que o escritor encontrou em sítios como as ruínas de Sans-Souci e a cidadela de La Ferriere, ganha em comparação com as buscas artísticas do "maravilhoso" por parte das vanguardas europeias, em particular, o surrealismo. Como nos lembra Paz Soldán (2008, p. 36), o ataque à literatura e pintura europeias é demolidor: de Lautreamont se diz "que lo suyo son simplemente códigos de lo fantástico"; dos intentos surrealistas de unir elementos incoerente em uma pintura, que se encontram, por exemplo, em Max Ernst, se diz que é apenas uma "vieja y embustera historia del encuentro fortuito del paraguas y de la máquina de coser sobre una mesa de disección"; de Dalí, Carpentier menciona "fórmulas consabidas que hacen de ciertas pinturas um monótono baratillo de relojes amelcochados" (CARPENTIER, 1984, p. 8); também há ataques a Magritte e De Chirico.

\section{GANPHLAC}

Revista Eletrônica da ANPHLAC, ISSN 1679-1061, No. 17, p. 107-138, jul./dez. 2014. http://revista.anphlac.org.br 
Carpentier despedaça as buscas das vanguardas europeias com o fanatismo de um converso. ${ }^{9}$ Como dito antes, o escritor cubano passou muitos anos em Paris e foi fortemente influenciado pela corrente surrealista, a ponto de sua primeira novela, ;EcueYamba-O!, não poder ser entendida sem o diálogo com a escola europeia. Além disso, Carpentier escreveu muitos artigos que elogiavam o trabalho de Breton, De Chirico e outros artistas europeus de vanguarda. No entanto, seu retorno ao continente americano levou-o a retificar-se. Como nos lembra Paz Soldán, obsessivo como estava com o desejo de encontrar uma forma própria de narrar a realidade e a história americanas, Carpentier prontamente chegou à conclusão de que as vanguardas europeias o levavam a um caminho sem saída. Tratava-se, na ótica do escritor cubano, de uma "artimaña literaria", de "trucos de prestidigitación" que não remetiam a verdadeiras realidades. Para ele, esses artifícios se haviam convertido em fórmulas prontas e automáticas, em lugares-comuns que empobreciam o artista: "a fuerza de querer suscitar lo maravilloso a todo trance, los taumaturgos se hacen burócratas" (CARPENTIER, 1984, p. 8-11).

É interessante notar que, apesar do empenho de Carpentier de apartar a sua novela da corrente surrealista, a chave para interpretação adequada de El reino de este mundo se encontra exatamente nas ideias propostas pela vanguarda europeia. Como salienta Ramón Cantero Pérez (1985, p. 227), aquilo que Carpentier decidiu chamar de "real maravilhoso", especialmente aplicado à sua novela sobre o Haiti, não deixa de ser uma visão estética do mundo preconizado pelo surrealismo. E, segundo Chiampi (1980, p. 34), críticos literários do porte de Emir Rodríguez Monegal não hesitaram em apontar as coincidências essenciais entre o merveilleux surrealista e aquele propalado por Carpentier.

O grupo de escritores franceses que o intelectual cubano encontrou em Paris nas décadas de 1920 e 1930, cansados da cultura ocidental europeia, procuravam novos meios de expressão e compreensão da realidade. A incitação da imaginação e o reconhecimento de que o sonho e a realidade não estão necessariamente em campos

\footnotetext{
${ }^{9}$ A identidade buscada pelo escritor é necessariamente relacional, ou seja, sempre produzida em relação a outra. Acima de tudo, é construída por meio da diferença e da exclusão. Define-se pelo o que ela não é, em outras palavras, outra identidade que mesmo não sendo igual (e sim oposta) fornece as condições para que ela exista. Ao afirmar a primazia da minha identidade - por exemplo, latino-americana - parece necessário colocá-la em oposição a outra identidade que é, então desvalorizada - o europeu. Segundo Stuart Hall, isso implica o reconhecimento radicalmente perturbador de que é apenas por meio da relação com o outro, da relação com aquilo que não é, com precisamente aquilo que falta, com aquilo que tem sido chamado de seu exterior constitutivo, que o significado "positivo" de qualquer termo - e, assim, sua "identidade" - pode ser construído (HALL, 2003, p. 103-133).
}

\section{GANPHLAC}

Revista Eletrônica da ANPHLAC, ISSN 1679-1061, No. 17, p. 107-138, jul./dez. 2014. http://revista.anphlac.org.br 
opostos da experiência humana eram partes essenciais das propostas do grupo de André Breton. Em outras palavras, o princípio geral do surrealismo - a noção de que o sonho interfere e faz parte da realidade e a tentativa de retomar o lugar de destaque ocupado pelo maravilhoso dentro da Literatura, como forma de libertação do racionalismo -, incitaram Carpentier a transladar a técnica surrealista para o tema americano.

Assim, aplicar os novos meios de expressão e compreensão da realidade indicados pelas vanguardas da arte europeia a uma América virgem, com suas paisagens, gentes e história se tornou a grande obsessão narrativa de Carpentier. Por isso, em El reino de este mundo, Carpentier não se afasta totalmente das técnicas surrealistas, pelo contrário, toma delas a expressão, a linguagem e a visão estética. Através do romance, ainda na perspectiva de Cantero Pérez, o escritor cubano demonstra que se pode ser surrealista sem necessariamente acatar a totalidade dos preceitos do surrealismo. E, de fato, o que Carpentier aprendeu na Europa acabou por deixar rastros em sua obra. Sua ênfase numa civilização ocidental em crise, a escravidão do homem moderno frente à máquina, a busca pelo primitivismo e a noção de um mundo que desmorona, desgastado pelo tempo e pela ação do homem são temas que aparecem continuamente no prólogo, na obra citada e nos romances posteriores do escritor cubano (CANTERO PEREZ, 1985, p. 229).

Portanto, por mais que a narrativa de Carpentier reivindique uma cultura ou uma literatura específica ou genuinamente hispano-americana, libertando-se dos padrões estilísticos europeus do pós-I Guerra, é impossível negar a influência que esse mesmo pensamento exerceu sobre o autor ao formular o seu principal conceito. A diferença, no entanto, subsiste na sua posição de ataque ao "maravilhoso" inventado na Europa em comparação ao genuíno ato de fé que inspiraria a criação do "real maravilhoso" na América.

Está aí, diz Carpentier referindo-se ao Haiti em seu prólogo, um lugar onde o real maravilloso se encontra em cada rincão e em cada momento: "Había respirado la atmósfera creada por Henri Christophe, monarca de increíbles empeños, mucho más sorprendente que todos los reyes crueles inventados por los surrealistas" (CARPENTIER, 1984, p. 8). Significativamente, o encontrado em um lugar da América logo se converte, para Carpentier, em uma metonímia de todo o continente americano.

Segundo Paz Soldán (2008, p. 37), no prólogo do romance o real maravilhoso essencializa-se e se torna um "patrimonio de la América entera". Obviamente, as buscas

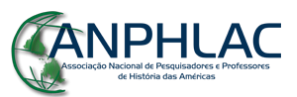

Revista Eletrônica da ANPHLAC, ISSN 1679-1061, Nº. 17, p. 107-138, jul./dez. 2014. http://revista.anphlac.org.br 
artísticas do escritor cubano não são menos artificiais que as do surrealismo europeu. Nesse sentido, o interessante é destacar a forma como se legitima um projeto literário: através da contraposição com a arte europeia e seu posterior descarte, e através do gesto político, controvertido, de dar a um aspecto do continente uma qualidade essencialista capaz de generalizar a todo o continente.

A indagação sobre o que é a América tem sido, sistematicamente, desde as suas viagens pela selva americana, a força propulsora da literatura de Carpentier. Existe em seus textos da década de 1940 uma necessidade de definir a cultura latino-americana no contexto ocidental, de identificar-se diante das diversas formas de colonização, de criar um sentido e um método de conhecimento para a sua realidade histórica. Essa intenção de traduzir a América através de seus livros se tornou uma ideologia que Carpentier não abandonou ao longo de sua vida. Para exemplificar, transcrevo abaixo mais uma passagem do prólogo de El reino de este mundo:

[...] Porque es menester advertir que el relato que va a leerse ha sido estabelecido sobre una documentación extremadamente rigurosa que no solamente respeta la verdad histórica de los acontecimientos, los nombres de personajes - incluso secundarios -, de lugares y hasta de calles, sino que oculta, bajo su aparente intemporalidad, un minucioso cotejo de fechas y cronologías. Y sin embrago, por la dramática singularidad de los acontecimientos, por la fantástica apostura de los personajes que se encontraron, en determinado momento, en la encrucijada mágica de la Ciudad del Cabo, todo resulta maravilloso en una historia impossible de situar en Europa, y que es tan real, sin embargo, como cualquier suceso ejemplar de los consignados, para pedagógica edificación, en los manuales escolares. ¡Pero qué es la historia de América toda sino una crônica de lo real maravilloso? (CARPENTIER, 1984, p. 14)

Qual a necessidade de se afirmar, naquilo que é tido como a introdução à leitura do romance, que a história que nos será narrada foi baseada num cotejo de datas e cronologias minucioso e, além disso, respeita a verdade histórica dos fatos? Podemos aferir que a ideia é afirmar, como já citado, que a realidade latino-americana possui uma especificidade: o maravilhoso não é fruto da inventividade artística, como acontece na Europa, ${ }^{10}$ mas, antes, uma característica do próprio continente, e que isso pode ser provado pela pesquisa de seus acontecimentos históricos.

${ }^{10}$ Como assinala Jorge Quiroga em seu livro Carpentier: em busca do real maravilhoso, o escritor cubano, no prólogo de El reino de este mundo, ataca o surrealismo, fala dos "burocratas do maravilhoso", do maravilhoso obtido à custa de clichês e de truques. Em sua última novela, La consagración de la

\section{GANPHLAC}

Revista Eletrônica da ANPHLAC, ISSN 1679-1061, No. 17, p. 107-138, jul./dez. 2014. http://revista.anphlac.org.br 
Lidos juntos, o prólogo e o romance ganham importância. Como salienta Paz Soldán (2008, p. 35), o ensaio, por seu tom combativo e propositivo, por suas polêmicas tomadas de posição, foi muito influente em críticos e escritores na hora de consolidar, na segunda metade do século XX, a busca por uma estética própria diferenciada da Europa para a literatura e a arte da América Latina, enquanto a novela serviu como exemplo perfeito de como um projeto narrativo podia encontrar sua forma.

Assim, o escritor cubano Alejo Carpentier tornou-se um dos porta-vozes de uma nova literatura hispano-americana, amparada na valorização do continente e de uma cultura especificamente latino-americana, em teoria, bastante diversa daquela propagada em território europeu. No entanto, é também interessante observar que, embora se pretenda nova e fundacional, essa literatura ampara-se em formas narrativas que são europeias. Essa parece ser também a tônica do romance Los pasos perdidos, publicado no México em princípios de 1953.

\section{Los pasos perdidos: a consolidação de um projeto identitário}

Segundo González Echevarría (1985, p. 15-16), Los pasos perdidos é a obra principal de Alejo Carpentier, e uma das mais importantes da literatura hispanoamericana. Junto com El reino de este mundo e Guerra del tiempo (1958), fez do escritor cubano um homem de renome internacional já nos anos 50, antecipando a fama que haveriam de adquirir os novelistas do chamado boom da narrativa hispanoamericana nos anos 60 e 70. Ainda segundo esse mesmo autor, são tão transcendentes as perguntas que surgem desta novela de Carpentier que ela deve ocupar um lugar de importância, não somente na história da literatura, mas também do pensamento hispanoamericano.

O romance nos conta a história de um musicólogo, filho de mãe cubana e pai europeu, personagem e também narrador, que depois de haver participado da Segunda Guerra Mundial se vê enredado numa viagem de busca de instrumentos musicais indígenas na América do Sul. O primeiro capítulo da obra se passa fora da América, numa cidade não nomeada - que, segundo González Echevarría, poderia ser Nova York (GONZÁLEZ ECHEVARRÍA, 1985, p. 72); ou, na perspectiva de Dernival Venâncio

primavera, volta a atacar o movimento - essa atitude, portanto, como se vê, é uma constante na vida do escritor e denota um processo de afirmação da identidade latino-americana baseado na negação da Europa.

\section{GANPHLAC}

Revista Eletrônica da ANPHLAC, ISSN 1679-1061, No. 17, p. 107-138, jul./dez. 2014. http://revista.anphlac.org.br 
Ramos Júnior, Paris (RAMOS JÚNIOR, 2004, p. 18). É nesse local que somos apresentados ao personagem e à sua história de vida.

O que chama atenção desde o princípio da leitura da obra é a descrição que o narrador faz de sua vida dentro dessa cidade. O panorama apresentado ao leitor é catastrófico: a profissão, o casamento, as relações humanas, os círculos frequentados e a paisagem dentro desse ambiente parecem oprimir. Tudo é cinza numa cidade onde nada acontece. O automatismo de sua vida e as relações vazias com intelectuais que nada tinham a oferecer imergem gradativamente o personagem dentro de um mundo sem perspectivas. Cada vez mais amargurado, entediado e descrente no real significado da profissão que exerce, o narrador se deixa levar numa cidade envelhecida onde os dias passam como sempre. Diante disso, os anos eram contados dentro de uma existência incapaz de deixar uma única recordação válida.

No entanto, tudo parece mudar quando a perspectiva de voltar à América lhe é oferecida. Embora o personagem aceite a aventura com certo desconforto no início, segundo Ramos Júnior (2004, p. 21), quando ele chega à América a viagem ganha outra dimensão. Ele começa a tecer um contraponto entre o que encontrava pela frente e o mundo de Paris do pós-guerra, fazendo deste modo uma reavaliação da relação entre a América Latina e a moderna civilização europeia. Isto o leva a redefinir sua própria identidade cultural, seu sentimento de pertencimento cultural - e, por contínuo, de todos os latino-americanos. ${ }^{11}$ Nesse sentido, interessa-nos questionar qual Europa é descartada e qual América é construída dentro dessa viagem que também é uma descoberta e afirmação da identidade cultural do personagem.

Nos relatos de viagem pelo interior da Venezuela e também no prólogo do romance El reino de este mundo é possível observar um padrão de descrição do que é a América e do que é a Europa dentro do pensamento de Carpentier. Embora apresentem enredos e intenções distintas, o conjunto de textos apresenta um tom semelhante: a descrição de uma América exuberante, nova, pujante, que tem por antítese uma Europa velha, puída, desgastada e completamente desacreditada. Como analisamos, nesses

\footnotetext{
${ }^{11}$ Como nos lembra Dernival Venâncio Ramos Júnior, a viagem é um símbolo cultural importantíssimo dentro de várias culturas, inclusive do Ocidente. Ela está intimamente ligada à passagem, à iniciação, à fundação e à aprendizagem. Nas histórias, é depois de uma longa viagem de aprendizado que o retorna e funda, refunda ou redime uma ordem das coisas: um tempo, uma cidade, uma filosofia e/ou uma religião. Quando analisamos Los pasos perdidos, a viagem para o narrador-personagem adquire também uma enorme importância simbólica: ela é o retorno ao seio de origem, o resgate de uma essência perdida, o reencontro com sua identidade latino-americana (RAMOS JÚNIOR, 2004, p. 21).
}

\section{GANPHLAC}

Revista Eletrônica da ANPHLAC, ISSN 1679-1061, No. 17, p. 107-138, jul./dez. 2014. http://revista.anphlac.org.br 
textos anteriores Carpentier empreende uma crítica mordaz, avassaladora sobre todos os paradigmas da arte, cultura e pensamento europeus, embora não consiga se desprender completamente de formas de descrever a América que são essencialmente formadas a partir do velho continente. Essa perspectiva de encarar os dois continentes se repete nos capítulos iniciais de Los pasos perdidos, seja pela vida medíocre e desprovida de sentido levada a cabo pelo personagem fora da América, seja pela completa negação dos símbolos máximos do esplendor cultural europeu, destacando-se ainda a necessidade de ressaltar uma natureza exuberante e indomável em seu retorno ao continente americano.

Cuando mejor dispuesto me encontraba para escuchar alguna música, luego de tanto ignorarla, tenía que brotar esto que ahora se hinchaba en crescendo a mis espaldas. Debí suponerlo, al ver entrar a los coristas al escenario. Pero también podía haberse tratado de un oratorio clásico. Porque de saber que era la Novena Sinfonía lo que presentaban los atriles, hubiera seguido de largo bajo el turbión. Si no toleraba ciertas músicas unidas al recuerdo de enfermedades de infancia, menos podía soportar el Freunde, Schöner Gotterfunken, Tochter aus Elysium! que había esquivado, desde entonces, como quien aparta los ojos, durante años, de ciertos objetos evocadores de una muerte. Además, como muchos hombres de mi generación, aborrecía cuanto tuviera um aire "sublime". La Oda de Schiller me era tan opuesta como la Cena de Montsalvat y la Elevación del Graal... (CARPENTIER, 1985, p. 79-80)

Como nos lembra González Echevarría (1985, p. 47), escrito pouco tempo depois do final da Segunda Guerra Mundial, cuja presença na memória do protagonistanarrador é quase obsessiva, Los pasos perdidos descarta, com muito pessimismo, o presente e o futuro da civilização ocidental. ${ }^{12}$ Esse descarte dos baluartes do pensamento europeu encontra no ódio à Nona Sinfonia de Beethoven seu ponto culminante. A decadência do mundo urbano, embasado no já comentado livro de Spengler, é cenário para o desfile de ironias ácidas do personagem em relação à composição símbolo da cultura europeia. A Ode à alegria, de Schiller, e seus trechos citados na parte mais conhecida da Nona Sinfonia ironicamente despertavam a sensação de morte no personagem; seu ar "sublime" aborrecia não apenas ao narrador, mas a muitos homens de sua geração.

\footnotetext{
12 É importante reforçar que a II Guerra Mundial aprofundou o fỉm da crença no progresso, na razão iluminista e na centralidade e unicidade do mundo que a modernidade europeia havia engendrado após a Revolução Francesa e a Revolução Industrial. Em todos os sentidos, o modelo de mundo que foi imposto pelo Imperialismo do século XIX e início do século XX ao resto do planeta como o lugar para o qual toda a humanidade deveria rumar seria amplamente questionado dentro do pensamento latino-americano do período. A literatura do continente não escapou a essas discussões.
}

\section{GANPHLAC}

Revista Eletrônica da ANPHLAC, ISSN 1679-1061, No. 17, p. 107-138, jul./dez. 2014. http://revista.anphlac.org.br 
E é fugindo dessa vida sem perspectiva, numa Europa completamente desgastada pela guerra e por tudo que nela havia de sublime, que o personagemprotagonista embarca com sua amante Mouche - amiga que se formara intelectualmente no brechó surrealista ${ }^{13}$ - num avião rumo à América.

É importante lembrar que o personagem havia vivido a infância, sua primeira formação, em Havana. Sua estadia na Europa era fruto da criação paterna, da memória do pai que insistia que suas origens, as dele e as do filho, estavam na civilização europeia. No entanto, a Europa relembrada com certo lirismo pelo pai não era a mesma encontrada pelo personagem.

Vale destacar ainda que a geração de intelectuais latino-americanos da qual Carpentier faz parte optou por apresentar uma América bastante diversa do olhar europeu do século XIX e início do XX. Como nos lembra Patricia Funes, até o início do XX a miragem de uma Europa vista como centro difusor da cultura e da civilização alimentava o sonho de muitos intelectuais do continente. As duas grandes guerras e a crise de paradigmas por elas estabelecida fez surgir uma consciência, amplamente difundida pela produção ensaística do continente, de que as respostas da América se encontravam em seu próprio território, e não fora - Europa ou EUA -, como há muito se acreditava. Assim, a negação do pai e das lembranças de uma Europa idealizada ganham sentido na narrativa de Carpentier. É contra estes intelectuais que enxergavam na viagem à Europa uma oportunidade - o velho continente como catalisador de forças e talentos ainda em embrião - que seu discurso literário se levanta.

Por isso, como nos lembra Ramos Júnior (2004, p. 21-22), ao retornar, depois de tantos anos, quando chega à costa do Caribe, ainda do avião, de imediato o personagem percebe que "había algo como un polen maligno en el aire - polen duende, carcoma impalpable, moho volante - que se ponía a actuar, de pronto, con misteriosos designios, para abrir lo cerrado y cerrar lo abierto, malear lo garantizado" (CARPENTIER, 1985, p. 106-107). O contato com a diferença americana, com um mundo que pode desarticular os cálculos e medidas tão caras ao racionalismo ocidental, primeiro o estremece, depois o fascina. Se a Europa do primeiro capítulo decepciona por sua decrepitude, a América anunciada no capítulo seguinte surge pujante diante de uma

${ }^{13}$ Carpentier descreve com muita ironia, no primeiro capítulo do livro, o círculo de intelectuais frequentado por ele e Mouche, deixando entrever a contenda que já havia proposto ao surrealismo europeu desde o prólogo de El reino de este mundo. Todas as referências à formação intelectual de Mouche são vistas como improfícuas e absolutamente vazias.

\section{CANPHLAC}

Revista Eletrônica da ANPHLAC, ISSN 1679-1061, No. 17, p. 107-138, jul./dez. 2014. http://revista.anphlac.org.br 
citação de Shelley: "Ha! I scent life". Aqui, no continente latino-americano, deixa claro Carpentier, está o espaço da vida.

Assim, a descrição da natureza americana na obra segue critérios anteriormente observados. Em seus relatos de viagem pelo interior da Grande Savana Venezuelana, em 1947, Carpentier deixa clara sua estupefação diante de uma paisagem exuberante e grandiosa, capaz de vencer os intentos da Conquista europeia. Essa mesma natureza volta a aparecer em Los pasos perdidos, dessa vez, para vencer os intentos da civilização em domesticá-la.

Durante centenares de años se había luchado contra raíces que levantaban los pisos y requebrajaban las murallas; pero cuando un rico proprietario se iba por unos meses a París, dejando la custodia de su residencia a servidumbres indolentes, las raíces aprovechaban el descuido de canciones y siestas para arquear el lomo en todas partes, acabando en veinte días con la mejor voluntad funcional de Le Corbusier. (CARPENTIER, 1985, p. 105-106)

É nessa América indomável que se faz o encontro do personagem com suas raízes culturais. O contato com a língua materna é descrito no livro quase como um ritual de possessão: como nos lembra Ramos Júnior (2004, p. 25), o prazer sentido, saboreado, pela penetração lenta do Espanhol pelos ouvidos, pelos poros, o leva diretamente para o mundo de sua infância e para a poesia de seus primeiros dias.

Pero ahora, una rara voluptuosidad adormece mis escrúpulos. Y una fuerza me penetra lentamente por los oídos, por los poros: el idioma. He aquí, pues, el idioma que hablé en mi infancia; el idioma en que aprendí a leer y a solfear; el idioma enmohecido en mi mente por el poco uso, dejado de lado como herramienta inútil, en país donde de poco pudiera servirme. Esto, Fabio, iay dolor!, que ves agora. Esto Fabio... Me vuelve a la mente, tras de largo olvido, ese verso dado como ejemplo de interjección en una pequeña gramática que debe estar guardada en alguma parte con un retrato de mi madre y un mechón de pelo rubio que me cortaron cuando tenía seis años. Y es el idioma de ese verso el que ahora se estampa en los letreros de los comercios que veo por los ventanales de la sala de espera; ríe y se deforma en la jerga de los maleteros negros; se hace caricatura en un ¡Biva el Precidente!, cuyas faltas de ortografía señalo a Mouche, con orgullo de quien, a partir de ese instante, será su guia e intérprete en la ciudad desconocida. Esta repentina sensación de superioridad sobre ella vence mis últimos escrúpulos. No me pesa haber venido. (CARPENTIER, 1985, p. 108)

\section{GANPHLAC}

Revista Eletrônica da ANPHLAC, ISSN 1679-1061, No. 17, p. 107-138, jul./dez. 2014.

http://revista.anphlac.org.br 
A partir de então, a sensação de não pertencimento ao mundo europeu se coloca ainda com mais força, aumentando exponencialmente na medida em que ele empreende sua viagem rumo ao interior do continente e da selva americana. É interessante observar que o tropo narrativo da viagem de descoberta rumo ao coração da selva foi bastante frequentado pelos literatos europeus de final do século XIX e início do XX. De todos os romances e relatos produzidos, merece destaque o livro Heart of darkness, de Joseph Conrad, escrito entre 1898 e 1899. A narrativa de Conrad está diretamente ligada, como lembra o crítico literário Edward Said em Cultura e imperialismo (1995, p. 55), à força redentora, bem como à devastação e ao horror da dimensão europeia no mundo negro. $\mathrm{O}$ romance de Conrad inicia com a narrativa do protagonista Marlow sobre sua viagem à África, como funcionário de uma importante empresa francesa vendedora de marfim. $\mathrm{O}$ fio narrativo que conduz a história contada por Conrad é a descoberta que o homem civilizado faz do mundo selvagem. Por isso, o que impera nas descrições do mundo africano é um sentimento de estranhamento, deslumbre e temor. A solidão parece ser também elemento central da história, já que não se vislumbra a possibilidade de um mundo civilizado. A descrição de uma terra não tocada pela mão do homem e, portanto, virgem, obedece a uma lógica narrativa que não reconhece no nativo a possibilidade da construção de uma civilização. Assim, o paralelo entre as narrativas de Carpentier, até aqui analisadas, e Heart of darkness é quase inevitável. O curso incessante da viagem, a qual, apesar de todos os obstáculos, avança pela selva, pelo tempo, por entre as dificuldades, até o coração da selva, é o ponto de contato entre Los pasos perdidos de Carpentier e Conrad. É interessante observar que as descrições da natureza em Conrad tendem a concentrar sua narração numa terra pujante, mas, sobretudo, numa região vazia, que parecia não ser habitada por ninguém, e o mesmo acontece com Carpentier. Além disso, personagens afetados pela natureza e pelo convívio com o coração da selva são aspectos centrais na narrativa tanto de um quanto de outro. Isso demonstra, mais uma vez, o argumento desenvolvido ao longo do artigo, de que os padrões narrativos e descritivos de Carpentier obedecem a uma lógica discursiva europeia.

Voltando ao romance Los pasos perdidos, o (re)encontro do personagem principal com o mundo americano vai lentamente provocando o emergir de um outro homem:

Mientras los cambios de altitud, la limpidez del aire, el trastorno de las costumbres, el reencuentro con el idioma de mi infancia, estaban

\section{GANPHLAC}

Revista Eletrônica da ANPHLAC, ISSN 1679-1061, No. 17, p. 107-138, jul./dez. 2014. http://revista.anphlac.org.br 
operando en mí una especie de regreso, aún vacilante pero ya sensible, a un equilibrio perdido hacía mucho tiempo, en ella se advertían aunque no lo confesara todavía - indicios de aburrimiento. Nada de lo visto por nosotros hasta ahora correspondía, evidentemente, a lo que ella hubiera querido encontar en este viaje, en caso de que hubiesse querido encontrar algo, en realidad. (CARPENTIER, 1985, p. 134)

É importante salientar, como lembra Ramos Júnior (2004, p. 26), que à medida que a viagem se dá, vai se reforçando no texto de Carpentier a simbologia da passagem. A trajetória rumo a Santa Mónica de los Venados é descrita quase como um ritual de iniciação. O homem que lentamente vai emergindo percebe-se cada vez mais identificado com o mundo americano, o que provoca grandes estragos na relação com sua companheira de viagem, Mouche. Se, por um lado, a viagem resgata para o narrador um equilíbrio há muito tempo perdido, para Mouche ela significa o esgotar de suas forças físicas e mentais:

Cuando Mouche salió de la habitación, poco después del Alba, parecia más cansada que la víspera. Habían bastado las incomodidades de un día de rodar por carreteras difíciles, el lecho duro, la necesidad de madrugar, de someter el cuerpo a una disciplina, para provocar una suerte de descoloramiento de su persona. Quien tan pifante y vivaz se mostraba en el desorden de nuestras noches de allá, era aquí la estampa del desgano. Parecía que se hubiera empañado de la claridad de su cutis, y mal guardaba un pañuelo sus cabellos que se iban en greñas de un rubio como verdecido. Su expresión de desagrado la avejentaba de modo sorprendente, aldegazando, con fea caída de las comisuras, unos labios que los malos espejos y la escasa no le permitían pintar debidamente. (CARPENTIER, 1985, p. 163)

A francesa não se adapta à selva americana: é frágil demais, presunçosa em excesso, incapaz de lidar com tudo que estivesse fora das fórmulas e clichês que adquirira nos livros que lera. Por isso, incapaz de compreender o mundo americano senão pelas fórmulas do exotismo - o que logo deixa de funcionar -, Mouche se vê enredada numa viagem, para ela, completamente exaustiva. Talvez Mouche fosse europeia demais para a aventura que então se apresentava. Importante frisar que todos os passos do personagem de Carpentier o levam a delimitar sua diferença com a amiga francesa surrealista.

A relação com Mouche - ou melhor, o esgotamento de sua relação com a francesa - é ponto importante dentro do projeto de descoberta da identidade do personagem. Mouche representa a arte francesa e a própria Civilização Ocidental. Por

\section{GANPHLAC}

Revista Eletrônica da ANPHLAC, ISSN 1679-1061, No. 17, p. 107-138, jul./dez. 2014. http://revista.anphlac.org.br 
isso, na medida em que se aprofunda a identificação do narrador com o continente e os costumes da América, é natural que os laços que o prendem à amiga se dissolvam. A devoção de Mouche para com o surrealismo e as discussões do seu círculo de amigos são encaradas cada vez mais como superficiais e desprovidas de qualquer conteúdo válido. Assim, a contenda que Carpentier estabelece com o surrealismo francês já no prólogo de El reino de este mundo aparece também nas páginas de Los pasos perdidos, e ajuda a caracterizar tudo aquilo de que o personagem-narrador quer se livrar para se descobrir cada vez mais americano.

Essa situação piora com a inserção de um terceiro personagem: Rosário, mulher misteriosa que aparece, entre a vida e a morte, no caminho que o ônibus de nossos dois primeiros personagens faz a Los Altos. Rosário representa a mulher americana ou, na perspectiva de Carpentier, tipicamente americana: vive no mundo da magia e do encantamento, sua realidade é diversa da de Mouche. Quando se encontraram nas montanhas, ela estava indo levar um conjuro a seu pai doente; sua crença, se que é pode-se usar este termo, no sobrenatural não é nem estruturada em modelos e fórmulas; ela vive efetivamente o maravilhoso - e por isso se contrapõe a Mouche. Se Mouche representa na narrativa de Carpentier a Europa, o Surrealismo, a Arte Ocidental, Rosário, por outro lado, está associada ao maravilhoso, ao real maravilhoso. Na descrição e desenvolvimento dessas duas personagens, Carpentier deixa claro que a realidade do mundo americano é comandada por um princípio diverso do mundo europeu. E dessa realidade maravilhosa, representada por Rosário, quer o narrador se aproximar. Assim, à medida que a viagem envereda-se pelos rumos da selva americana, a aproximação e fulminante paixão por Rosário coloca em mundos opostos o personagem e Mouche:

[...] la joven crecía ante mis ojos a medida que transcurrían las horas, al estabelecer con el ambiente ciertas relaciones que me eran cada vez más percptibles. Mouche, en cambio, iba resultando tremendamente forastera dentro de un creciente desajuste entre su persona y cuanto nos circundaba. Un aura de exotismo se espesaba en torno a ella, estableciendo distancias entre su figura y las demás figuras; entre sus acciones, sus maneras, y los modos de actuar que aquí eram normales. Se tornaba, poco a poco, en algo ajeno, mal situado, excéntrico, que llamaba la atención, como llamaba la atención antaño, en las cortes crsitianas, el turbante de los embajadores de la Sublime Puerta. (CARPENTIER, 1985, p. 170)

\section{GANPHLAC}

Revista Eletrônica da ANPHLAC, ISSN 1679-1061, No. 17, p. 107-138, jul./dez. 2014. http://revista.anphlac.org.br 
Rosário representa a consolidação do encontro que o personagem faz com sua suposta identidade americana. Por isso, sentia-se "cada vez más cerca de Rosario, que embellecía de hora en hora, frente a la outra que difuminaba en su distancia presente" (CARPENTIER, 1985, p. 171). Mouche e tudo o que ela representava passam a ser, irremediavelmente, a partir desse momento, um fardo na viagem empreendida pelo narrador. Por isso, para se aproximar de Rosário, da América, de sua identidade perdida, a questão passava a ser, àquele momento, como livrar-se de Mouche.

À medida que o tempo passava, o asco que o narrador sentia em relação à sua primeira companheira de viagem só fazia crescer. As brigas e discussões constantes, assim como diferentes perspectivas diante do mundo americano, acarretaram num rompimento definitivo e necessário entre esses dois amantes que, agora, se descobriam partícipes de mundos completamente diferentes e opostos. A situação definitiva viria de uma surra empreendida por Rosário em Mouche:

Mouche aparece ahora, con la ropa empapada, pidiendo ayuda, como huyendo de algo terrible. Antes de haber podido dar un paso, veo Rosario, mal cubierta por un grueso refajo, que alcanza a mi amiga, la arroja al suelo de un empellón y la golpea bárbaramente con una estaca. Con la cabellera suelta sobre los ombros, escupiendo insultos, pegando a la vez con los pies, la madera y mano libre, nos oferece una tal estampada de ferocidad que corremos todos a agarrarla. Todavía se retuerce, patea, muerde a quienes la sujetan, con un furor que se traduce en gruñidos roncos, en bufidos, por no encontrar la palabra. Cuando levanto a Mouche, apenas si puede tenerse en pie. Un golpe le ha roto dos dientes. Le sangra la nariz. Está cubierta de arañazos y desollones. (CARPENTIER, 1985, p. 207-208)

No enredo de Los pasos perdidos, esse é um momento importantíssimo. Mouche se torna, ao longo da viagem, uma excentricidade: seu desconcerto e não adaptação ao ambiente e costumes culturais americanos, ou melhor, seu excessivo ar europeu, sublime, faz com que não se entenda com os códigos culturais americanos. Ela, que encontrava justificativas intelectuais para os excessos do sexo, resolve insinuar-se a Rosário na beira do rio enquanto se banhavam. Prontamente, a tentativa se mostra desastrosa. Humilhada, surrada, com o corpo todo marcado por escoriações, Mouche mal podia pôr-se de pé. Este é o golpe derradeiro, o ponto final da presença afrancesada de Mouche no interior da selva americana. Depois desse episódio, a pintora gradativamente adoece, obrigando-os a arquitetar sua volta para o povoado de Los Altos.

\section{GANPHLAC}

Revista Eletrônica da ANPHLAC, ISSN 1679-1061, No. 17, p. 107-138, jul./dez. 2014. http://revista.anphlac.org.br 
É importante lembrar, como afirma Ramos Júnior (2004, p. 33-34), que quando Mouhe é deixada para trás, ocorre a revelação dos segredos da floresta. O canal que dá acesso a Santa Mónica de los Venados se abre. Ainda na perspectiva do autor, os segredos da natureza americana estão vedados à surrealista Mouche - assim como se fecharam para os pintores surrealistas que tentaram se aproximar deles -, mas estão abertos a Rosário. A misteriosa mulher americana permite ao nosso personagem entrar em contato com os segredos do mundo americano. Torna-lhe possível acessar o paraíso, a primeira cidade, Santa Mónica de los Venados, onde a inspiração artística, o ímpeto criador o monta a galope, e ele compõe sua sinfonia a partir do texto da Odisséia $^{14}$ de Homero. A criação artística, estagnada na Europa, ressurge com assombrosa criatividade na América.

Assim, a descoberta da identidade americana, ou melhor, o seu retorno a ela, no livro, obedece a um critério bastante específico. A passagem se dá por etapas: primeiro, identificamos um personagem não enquadrado, insatisfeito diante de um mundo esgotado (Europa); depois, entendemos que essa sensação de não pertencimento vem de um desarraigamento para com a terra materna - sensação que se intensifica quando o personagem entra em contato com a língua espanhola e descobre, ao pisar no continente, uma terra de vida, pujança, com enormes possibilidades; inicia seu distanciamento da Europa através do esgotamento de sua relação com Mouche, que se intensifica quando encontra Rosário (América). Para se descobrir americano, nosso narrador precisou rechaçar qualquer resquício de sua ligação com a Europa.

Esses elementos já são suficientes para se perceber a crítica ao modernismo latino-americano, que, juntamente com a crítica ao surrealismo, levam a pensar numa redefinição, numa tentativa de buscar um novo sentido para a arte produzida na América Latina. Essa redefinição é, como já foi dito, uma redefinição de identidade cultural. Deixar Paris, como faz o personagem de Los pasos perdidos, pelo interior da América é fixar um novo centro para o mundo. Assim, para o narrador da obra, o retorno ao continente americano marca também o renascimento de um novo homem e uma nova consciência. O contato com o mundo americano proporciona ao personagem certa renovação. Sua vida ganha sentido, significado, objetivo.

\footnotetext{
${ }^{14}$ Aqui, é interessante observar a intertextualidade usada pelo escritor. Odisséia, texto épico atribuído a Homero, é o símbolo universal do retorno. Dentro de sua lógica narrativa, nenhum outro texto ilustraria tão precisamente a situação do personagem principal em seu retorno ao continente latino-americano.
}

\section{GANPHLAC}

Revista Eletrônica da ANPHLAC, ISSN 1679-1061, No. 17, p. 107-138, jul./dez. 2014. http://revista.anphlac.org.br 
Para González Echevarría (1985, p. 41), trata-se de uma novela autobiográfica, com todas as circunstâncias que isso implica. ${ }^{15} \mathrm{O}$ narrador de Los pasos perdidos (re)constrói sua própria imagem individual e original como americano e obtém uma ideia do que seria supostamente sua verdadeira identidade. Claro que os dados que traz de si próprio - a leitura do que seja ele, Alejo Carpentier -, quanto a ser um americano com suas características e problemáticas peculiares, adquirem proporções bem mais grandiosas e valiosas quando esses idênticos traços passam a compor o perfil identitário do povo americano.

No entanto, é interessante observar que, apesar dessa obsessão pela procura de uma identidade originalmente americana, o mundo europeu parece persistir. Encontrar a Nona Sinfonia americana, ao final do romance, é uma atitude europeizada de aproximar a descrição do mundo não conhecido às suas referências culturais. Tudo, na leitura de Carpentier, indica um europeu descrevendo a América: o exercício de aproximar sons e paisagens às referências europeias comprova isso. É interessante pensar também que o desbunde e o encantamento com a selva americana, tão cara ao romance, só é possível àquele que permanece de fora da realidade descrita. Embora se identifique com aquilo que descreve, suas reações de espanto configuram-no como forasteiro, que, por se situar do lado de fora, supostamente compreenderia o funcionamento do que seria essa essência da América.

Esses elementos são suficientes para se pensar o lugar que Carpentier ocupa como intelectual latino-americano e, em certo sentido, a geração do boom que o procede. Essa consciência de pertencimento à América, dada através do exílio, do lado de fora, criou uma forma bastante específica de representar o continente: se, por um lado, há uma tentativa de redefinição de identidade baseada numa representação positiva da América Latina e no descarte da civilização europeia (América como tese e Europa como antítese), por outro, a forma como esses espaços são representados e descritos obedece ainda a uma lógica narrativa europeia.

15 Como lembra González Echevarría, os detalhes autobiográficos e históricos incorporados por Carpentier a Los pasos perdidos são numerosos. Durante muitos anos Carpentier dedicou-se à publicidade, em um emprego que exigia horas regulares de trabalho, assim como o protagonista de Los pasos perdidos. Também como ele, Carpentier dedicou suas férias de verão a uma viagem pela selva americana. Ao chegar em Caracas, em 1945, Carpentier e sua esposa Lilia foram surpreendidos por um golpe de estado, com tiroteios nas ruas, que forçaram aos dois permanecer refugiados num hotel, como o protagonista e Mouche no romance. Além disso, salta aos olhos a descrição do protagonista, homem pertencente a duas culturas, que quer redescobrir suas raízes hispano-americanas mediante uma viagem de regresso à origem, e cujo emprego como publicitário o condena a vender seus conhecimentos e talentos de musicólogo e compositor (GONZÁLEZ ECHEVARRÍA, 1985, p. 41).

\section{GANPHLAC}

Revista Eletrônica da ANPHLAC, ISSN 1679-1061, No. 17, p. 107-138, jul./dez. 2014. http://revista.anphlac.org.br 
Carpentier ganhou dois prêmios literários na França durante os anos 50, uma companhia cinematográfica norte-americana quis levar Los pasos perdidos à tela de cinema e um crítico do Times de Nova York pediu o Prêmio Nobel para o cubano em 1957. Além do reconhecimento, Carpentier é um dos precursores de Carlos Fuentes, Gabriel García Márquez e Mario Vargas Llosa não só no que concerne à fama; sua obra torna possível as obras desses escritores.

Como escreve González Echevarría, Los pasos perdidos, com seus seis capítulos, possui a forma da semana do Gênesis, anunciando assim a forma mais concreta da existência de um sétimo capítulo-dia "que será ese domingo fabuloso de la ficción. La nueva novela hispanoamericana se escribe en ese domingo augurado por Carpentier" (GONZÁLEZ ECHEVARRÍA, 1985, p. 53).

\section{Considerações finais}

Como nos lembra Jacques Joset (1987, p. 92), a narrativa hispano-americana do século XX apresenta uma superabundância de tendências, uma multiplicidade de escritores de qualidade difíceis de classificar. O lugar que cedemos a esses escritores é também, muitas vezes, arbitrário. As cômodas etiquetas de "realismo mágico" ou de "real maravilhoso" recobrem não somente uma tentativa de adaptação à prosa dos recursos estilísticos próprios da poesia como também uma visão mítica, alucinada da vida mais cotidiana. Esses conceitos, que se mostram inoperantes tanto na teoria como na história literária, permitem ao menos indicar um campo de diálogo entre os literatos do período. A intenção do artigo foi percorrer a vida e as obras iniciais do escritor cubano Alejo Carpentier, considerado por muitos historiadores e críticos literários o grande articulador dessa ideia que se tornou o selo narrativo da literatura hispanoamericana do período.

Considerado o pai mítico da geração do boom, Carpentier escreveu ao longo das décadas de 1940 e 1950 algumas obras fundamentais para a elaboração do argumento que se tornou a base da literatura hispano-americana da segunda metade do século XX: a América como espaço do maravilhoso. Além disso, ao elaborar suas narrativas e descrições da América, o escritor cubano criou representações do continente que foram apropriadas e difundiram-se como paradigma explicativo da realidade histórica latinoamericana.

\section{GANPHLAC}

Revista Eletrônica da ANPHLAC, ISSN 1679-1061, No. 17, p. 107-138, jul./dez. 2014. http://revista.anphlac.org.br 
Dessa forma, a primeira etapa do artigo centrou sua análise numa coletânea de ensaios publicada pelo autor em 1947, sob a rubrica de Visión de América. Nesses primeiros textos, nossa análise se concentrou, sobretudo, na formulação de uma identidade latino-americana baseada na detratação da Europa e na valorização da América, tendo por pressuposto o engrandecimento de sua natureza. As descrições da selva americana, escritas sob a forma de um diário de bordo, enfatizaram, sobretudo, a grandiosidade, a originalidade e a pujança do continente.

Esses relatos, originalmente publicados no jornal El Nacional de Caracas e na revista Carteles, forneceram também material suficiente para a elaboração de dois romances: El reino de este mundo (1949) e Los pasos perdidos (1953). O artigo privilegiou, em especial, a análise do prólogo do livro El reino de este mundo, texto gerador de um intenso debate sobre a ideia de unidade latino-americana através do conceito de maravilhoso. O prólogo do livro, por muito tempo mais famoso que o próprio romance, é quase um manifesto; ele inaugura um debate importante sobre a especificidade da identidade latino-americana que aparecerá como pedra de toque de obras posteriores do escritor, em particular, do romance Los pasos perdidos.

Um elemento decisivo para a compreensão desses textos de Carpentier é pensar como a consciência de pertencer à América e se descobrir profundamente latinoamericano se deu através do exílio, criando uma forma bastante específica de representar o continente. É importante circunscrever a geração de intelectuais hispanoamericanos, da qual Carpentier faz parte, dentro de uma perspectiva que pensa a América a partir da Europa. Se, por um lado, há uma tentativa de redefinição de identidade baseada numa representação positiva do continente e no descarte da civilização europeia, por outro, a forma como esses espaços são representados e descritos obedece quase sempre a uma lógica discursiva construída no Velho Mundo.

Isso criou um discurso híbrido que, ao mesmo tempo em que tenta construir uma imagem positiva e afirmativa da identidade do continente, o faz a partir de uma lógica descritiva europeia. Esse fato, talvez, explique o sucesso desses escritores dentro e fora da América, em especial, na Europa, acostumada a pensar o continente dentro desse espaço comum revisitado pelos autores do real maravilhoso.

\section{Referências documentais e bibliográficas}

\section{GANPHLAC}

Revista Eletrônica da ANPHLAC, ISSN 1679-1061, No. 17, p. 107-138, jul./dez. 2014. http://revista.anphlac.org.br 


\section{Documentais}

CARPENTIER, Alejo. A literatura do maravilhoso. São Paulo: Vértice, 1987. 1984. . El reino de este mundo. Habana: Editorial Letras Cubanas, Dom Quixote, 1971. Literatura e consciência política na América Latina. Lisboa: Los pasos perdidos. Madrid: Cátedra / Letras Hispânicas, 1985. Visão da América. São Paulo: Martins Fontes, 2006.

\section{Bibliográficas}

CANTERO PÉREZ, Ramón. "Huellas surrealistas en El reino de este mundo, de Alejo Carpentier". Anales de la Universidad de Murcia. Vol. 43, no 1-2,1985. Disponível em: http://digitum.um.es/xmlui/handle/10201/12880. Acesso em 19/12/2014.

CARPEAUX, Otto Maria. Prefácio. In: CARPENTIER, Alejo. O século das luzes. Rio de Janeiro: Editorial Labor do Brasil, 1976.

CHIAMPI, Irlemar. O realismo maravilhoso: forma e ideologia no romance hispanoamericano. São Paulo: Editora Perspectiva, 1980.

FERNANDES, Luiz Estevam de Oliveira. Patria mestiza: memória e história na invenção da nação mexicana entre os séculos XVIII e XIX. Tese de Doutorado. Campinas: UNICAMP/IFCH, 2009.

FUNES, Patricia. Salvar la nación: intelectuales, cultura y política en los ãnos veinte latinoamericanos. Buenos Aires: Prometeo Libros, 2006.

GILMAN, Claudia. Entre la pluma y el fusil: debates y dilemas del escritor revolucionario en América Latina. Buenos Aires: Siglo XXI, 2003.

GONZÁLZ ECHEVARRÍA, Roberto. Introducción. In: CARPENTIER, Alejo. Los pasos perdidos. Madrid: Ediciones Cátedra, 1985.

JOSET, Jacques. A literatura hispano-americana. São Paulo: Martins Fontes, 1987.

MELO, Carlos Augusto. Alejo Carpentier e sua 'viagem interior' pela selva americana. Raído, Dourados, MS, v. 4, n. 7, p. 93-104, jan./ jun. 2010.

OLIVEIRA, Flávia Preto de Godoy. Entre o fabuloso e o verossímil: crônicas e epistemologia no processo de cognição da América. Dissertação de Mestrado. Campinas: UNICAMP/IFCH, 2010.

\section{GANPHLAC}

Revista Eletrônica da ANPHLAC, ISSN 1679-1061, No. 17, p. 107-138, jul./dez. 2014. http://revista.anphlac.org.br 
PAZ SOLDÁN, Edmundo. Alejo Carpentier: teoría y práctica de lo real maravilloso. In: Anales de Literatura Hispanoamericana, 2008, v. 37. p. 35-42.

PRATT, Mary Louise. Os olhos do império: relatos de viagem e transculturação. Bauru: EDUSC, 1999.

QUIROGA, Jorge. Alejo Carpentier: em busca do real maravilhoso. São Paulo: Editora Brasiliense, 1984.

RAMOS JÚNIOR, Dernival Venâncio. Cien anos de soledad - e o caribe $e$ o carnavalesco e o maravilhoso: um estudo histórico-cultural da obra de Gabriel García Márquez. Dissertação de Mestrado, Faculdade de Ciência Humanas e Filosofia/UFGO, 2004.

SAID, Edward. Cultura e imperialismo. São Paulo: Companhia das Letras, 1995.

SILVA, Tomaz Tadeu da (Org.). Identidade e diferença: a perspectiva dos estudos culturais. Petrópolis: Editora Vozes, 2003.

\section{GANPHLAC}

Revista Eletrônica da ANPHLAC, ISSN 1679-1061, No. 17, p. 107-138, jul./dez. 2014.

http://revista.anphlac.org.br 